\title{
Cytotoxicity, mode of action and antibacterial activities of selected Saudi Arabian medicinal plants
}

Victor Kuete ${ }^{1,2}$, Benjamin Wiench¹, Mansour S Alsaid ${ }^{3}$, Muhammad A Alyahya $^{3}$, Aimé G Fankam², Abdelaaty A Shahat ${ }^{3,4^{*}}$ and Thomas Efferth ${ }^{1 *}$

\begin{abstract}
Background: The flora of Saudi Arabia is one of the richest biodiversity areas in the Arabian Peninsula and comprises very important genetic resources of crop and medicinal plants. The present study was designed to investigate the cytotoxicity and the antibacterial activities of the organic extracts from twenty six Saudi Arabian medicinal plants. The study was also extended to the investigation of the effects of the extracts from the four best plants, Ononis serrata (SY160), Haplophyllum tuberculatum (SY177), Pulicaria crispa (SY179), and Achillea beiberstenii (SY-200) on cell cycle distribution, apoptosis, caspases activities and mitochondrial function in leukemia CCRF-CEM cell line.
\end{abstract}

Methods: A resazurin assay was used to assess the cytotoxicity of the extracts on a panel of human cancer cell lines whilst the microbroth dilution was used to determine the minimal inhibitory concentration (MIC) of the samples against twelve bacterial strains belonging to four species, Escherichia coli, Enterobacter aerogenes, Klebsiella pneumoniae and Pseudomonas aeruginosa.

Results: The best activity on leukemia cell lines were recorded with SY177 (IC 50 of $9.94 \mu \mathrm{g} / \mathrm{mL}$ ) and SY179 (IC 50 of $1.81 \mu \mathrm{g} / \mathrm{mL})$ against CCRF-CEM as well as Ach-b (IC $C_{50}$ of $\left.9.30 \mu \mathrm{g} / \mathrm{mL}\right)$ and $S Y 160\left(I C_{50}\right.$ of $\left.5.06 \mu \mathrm{g} / \mathrm{mL}\right)$ against HL60 cells. The extracts from SY177 and SY179 were also toxic against the seven solid cancer cell lines studied with the highest $I_{50}$ values of $31.64 \mu \mathrm{g} / \mathrm{mL}$ (SY177 against Hep-G2 cells). SY177 and Ach-b induced cell cycle arrest in G0/G1 and S phases whilst SY160 and SY179 induced arrest in G0/G1 phase. All the four plant extracts induced apoptosis in CCRF-CEM cells with the alteration of the mitochondrial membrane potential. In the antibacterial assays, only Ach-b displayed moderate antibacterial activities against E. coli and E. aerogenes ATCC strains (MIC of $256 \mu \mathrm{g} / \mathrm{mL}$ ), AG100Aтет and K. pneumoniae ATCC strains (MIC of $128 \mu \mathrm{g} / \mathrm{mL}$ ).

Conclusions: Finally, the results of the present investigation provided supportive data for the possible use of some Saudi Arabian plants investigated herein, and mostly Haplophyllum tuberculatum, Pulicaria crispa, Ononis serrata and Achillea beiberstenii in the control of cancer diseases.

Keywords: Antibacterial, Cytotoxicity, Mode of action, Medicinal plants, Saudi Arabia

\footnotetext{
* Correspondence: ashahat@ksu.edu.sa; efferth@uni-mainz.de

${ }^{3}$ Pharmcognosy Department, College of Pharmacy, King Saud University, P.O.

Box 2457, Riyadh 11451, Saudi Arabia

1 Department of Pharmaceutical Biology, Institute of Pharmacy and

Biochemistry, University of Mainz, Staudinger Weg 5, 55128 Mainz, Germany

Full list of author information is available at the end of the article
} 


\section{Background}

Medicinal plants constitute an important source of new candidates for therapeutic compounds, in regards to the chemical diversity found in several species. Many plantderived compounds are currently successfully employed in cancer chemotherapy, explaining the endeavor of researchers worldwide for the intensive search of new anti-neoplastic agents from the nature. The flora of Saudi Arabia is one of the richest biodiversity areas in the Arabian Peninsula and comprises very important genetic resources of crop and medicinal plants [1]. It was estimated that the flora of Saudi Arabia has a great medicinal species diversity, which is expected to be more than 1200 (over 50\%) out of its 2250 species [1]. Hence, the present study was designed to investigate the cytotoxicity and the antimicrobial activities of twenty six Saudi Arabian plants against leukemia and carcinoma cell lines. In addition, the effects of the four best plants namely Haplophyllum tuberculatum, Pulicaria crispa, Ononis serrata and Achillea beiberstenii on cell cycle distribution, apoptosis, caspases activities and mitochondrial function in leukemia CCRF-CEM cells were investigated.

\section{Methods}

\section{Plant material}

All the plants were collected from Tanhat protected area except Cleome ambliocarpa, Artemisia monosperma, Ononis serrata and Achillea beibersteni that were collected from Um-Rugum, Aldahua, Kaba and Albaha, respectively, (Saudi Arabia) in March 2010. The plants were identified by the Plants Taxonomy and Herbarium Unit. The voucher specimens (Table 1) have been deposited at the Herbarium of the Faculty of Pharmacy, King Saud University, Riyadh, Saudi Arabia.

\section{Extraction}

The aerial parts of plants were collected and dried under shade. The dried samples were powdered and used for solvent extraction. For extract preparation, $100 \mathrm{~g}$ of dried sample was extracted with $80 \%$ methanol for $48 \mathrm{~h}$ and the procedure was repeated once. The extracts were filtrated through Whatman No. 1 and combined, then concentrated using a rotary evaporator under reduced pressure at $40^{\circ} \mathrm{C}$. The dry extract obtained with each solvent was weighed. The percentage yield was expressed in terms of air dried weight of plant materials.

\section{Chemicals}

Doxorubicin, vinblastine and daunorubicin from SigmaAldrich (Munich, Germany) were dissolved in Phosphate Buffer Saline (PBS; Invitrogen, Eggenstein, Germany) at a concentration of $10 \mathrm{mM}$. Geneticin was purchased from Sigma-Aldrich at a concentration of $50 \mathrm{mg} / \mathrm{mL}$ in sterile-filtered water. Chloramphenicol (Sigma-Aldrich, St Quentin Fallavier, France) was used as reference antibacterial drug.

\section{Cell cultures}

Leukemia CCRF-CEM and HL-60 cells were maintained in RPMI 1640 medium (Invitrogen) supplemented with $10 \%$ fetal calf serum in a humidified $5 \% \mathrm{CO}_{2}$ atmosphere at $37^{\circ} \mathrm{C}$. Cells were kindly provided by Dr. J. Beck (Department of Pediatrics, University of Greifswald, Greifswald, Germany). Breast cancer cells transduced with control vector (MDA-MB-231-pcDNA3) or with cDNA for the breast cancer resistance protein BCRP (MDA-MB-231$B C R P$ clone 23 ) were maintained under standard conditions as described above for CCRF-CEM and HL-60 cells. Human wild-type HCT116 $\left(p 53^{+/+}\right)$colon cancer cells as well as knockout clones HCT116 $\left(p 53^{-/-}\right)$derived by homologous recombination were a generous gift from Dr. B. Vogelstein and H. Hermeking (Howard Hughes Medical Institute, Baltimore, MD). Non-transduced human glioblastoma multiforme U87MG cells and U87MG cells transduced with an expression vector harboring an epidermal growth factor receptor (EGFR) gene with a genomic deletion of exons 2 through 7 (U87MG. $\triangle E G F R$ ) were kindly provided by Dr. W. K. Cavenee (Ludwig Institute for Cancer Research, San Diego, CA). MDA-MB231-BCRP, U87MG. $\triangle E G F R$ and HCT116 (p53-/-) were maintained in DMEM medium containing 10\% FBS (Invitrogen) and $1 \%$ penicillin $(100 \mathrm{U} / \mathrm{mL})$-streptomycin $(100 \mu \mathrm{g} / \mathrm{mL})$ (Invitrogen) and were continuously treated with $800 \mathrm{ng} / \mathrm{mL}$ and $400 \mu \mathrm{g} / \mathrm{mL}$ geneticin, respectively. The multidrug resistance profile of these cell lines has been reported [32]. Human HepG2 hepatocellular carcinoma cells and the AML 12 normal heptocytes were obtained from the American Type Cell Culture Collection ATCC (USA). DMEM medium without geneticin was used to maintain MDA-MB-231, U87MG, HCT116 $\left(p 53^{+/+}\right)$, HepG2 and AML 12 cell lines. The cells were passaged twice weekly. All experiments were performed with cells in the logarithmic growth phase.

\section{Resazurin reduction assay}

Resazurin reduction assay [33] was performed to assess the cytotoxicity of the crude extracts towards various sensitive and resistant cancer cell lines. The assay is based on reduction of the indicator dye, resazurin, to the highly fluorescent resorufin by viable cells. Non-viable cells rapidly lose their metabolic capacity to reduce resazurin and, thus, do not produce fluorescent signals anymore. Briefly, adherent cells were detached by treatment with $0.25 \%$ trypsin/EDTA (Invitrogen) and an aliquot of $1 \times 10^{4}$ cells was placed in each well of a 96-well cell culture plate (Thermo Scientific, Germany) in a total volume of $200 \mu \mathrm{L}$. Cells were allowed to attach overnight and then were 
Table 1 Medicinal plants used in the present study

\section{Plant species/Family (Voucher specimen)}

Echium arabicum/Boraginaceae (15931)

Haplophyllum tuberculatum/Rutaceae (15932)

Senna italica/Caealpiniaceae (15933)

Pulicaria crispa/Asteraceae (15934)

Rhantarium epapposum/Asteraceae (15935)

Rumex vasicanus/Polygonaceae (15936)

Ducrosia anethifolia/Aplaceae (15937)

Heliotropium ramosissimum/Boraginaceae (15938)

Picris cyanocarpa/Asteraceae (15939)

Anthemis deserti/Asteraceae (15940)

Cleome ambliocarpa/Cleomaceae (15945)

Zilla spinosa/Brassicaceae (15946)

Ziziphus nummularia/Rhamnaceae (15947)

Neurada procumbens/Neuradaceae (15949)

Trigonella hamosa/Papilionaceae (15951)

Achillia fragrantissima/Asteraceae (15952)

Convolvulus prostates/Convolvulaceae (15953)

Cltrullus colocynthis/Cucurbitaceae (15954)

Emex spinosa/Polygonaceae (15955)

Rhazya strict/Apocynaceae (15957)

Scrophularia hypericifolia/Scrophulariaceae (15958)

Caylusea hexagyna/Resedaceae (15959)

Artemisia monosperma/Asteraceae (15960)
Antiplasmodial and antitrypanosomal activity [5]

Headaches and arthritis, to remove warts and freckles from the skin and also to treat skin discoloration, infections and parasitic diseases [6], it is used to treat malaria, rheumatoid arthritis and gynecological disorders [7]

Diarrhea, stomachache, female infertility, tuberculosis, asthma [8]

Treat inflammation and an insect repellent [9] and is also used as an herbal tea Skin infections and gastrointestinal disturbances and as an insecticide [10]

Treatment of pain, inflammation, bleeding, tinea, tumor, and constipation $[11,12]$, cough, headache, and fever [13]

Analgesic and pain reliever for headache, ackache, colic, and colds [14]

Treatment of gout, rheumatism, and as anti-inflammatory and healing agents [15] Treatment of indigestion, against intestinal nematodes and other parasites [16]

Herbal medicines, insecticides, and dyes, food additives, as well as an important source in aromatic and cosmetic industries [17]

Stomachics, rubefacients and in the treatment of scabies, rheumatic, fever, inflammation and a hypoglycemic agent, [18]

Antioxidant, antifungal, hepatoprotective and antiviral activities [19]

Antibacterial, analgesic activities and anthelmintics [20]

Diarrhea and dysentery; as well, it has been used as a tonic to 'increase heart and respiration functions

A condiment and seasoning in food preparations and hypoglycemic

Respiratory diseases and gastrointestinal disturbances [21]

Brain related disease, improve memory, skin disease [22]

Treat constipation, diabetes, edema, fever, jaundice, bacterial infections as well as cancer [23]

Purgative, diuretic, a remedy for stomach disorders, dyspepsia and colic [24]

Diabetes mellitus, fever, sore throat, inflammatory conditions and helminthiasis [25]

Antipyretic, febrifuge and anti-bacterial, as a remedy for evening fever, mouth dryness, constipation, prurigo, furunculosis, sore throat, ulcerous stomatitis, tonsillitis and in the treatment of cancer $[26,27]$

Anticancer (melanoma cell lines) [28]

Antispasmodic, anthelmintic and anti-hypertensive [29] 
Table 1 Medicinal plants used in the present study (Continued)

Ononis serrata/Fabaceae (15925) Antibiotic, antipyretic, anti-inflammatory, antifungal and antiseptic activities. Treat- 
treated with different concentrations of compounds. For suspension cells, aliquots of $2 \times 10^{4}$ cells per well were seeded in 96-well-plates in a total volume of $100 \mu \mathrm{L}$. The studied sample was immediately added in varying concentrations in an additional $100 \mu \mathrm{L}$ of culture medium to obtain a total volume of $200 \mu \mathrm{L} /$ well. After $24 \mathrm{~h}$ or $48 \mathrm{~h}$, $20 \mu \mathrm{L}$ resazurin (Sigma-Aldrich, Germany) $0.01 \% \mathrm{w} / \mathrm{v}$ in double distilled water $\left(\mathrm{ddH}_{2} \mathrm{O}\right)$ was added to each well and the plates were incubated at $37^{\circ} \mathrm{C}$ for $4 \mathrm{~h}$. Fluorescence was measured on an Infinite M2000 Pro $^{\mathrm{Tm}}$ plate reader (Tecan, Germany) using an excitation wavelength of $544 \mathrm{~nm}$ and an emission wavelength of $590 \mathrm{~nm}$. Each assay was done at least two times, with six replicate each. The twenty six studied plants were first tested on CCRFCEM and HL60 at $40 \mu \mathrm{g} / \mathrm{mL}$ and samples inducing less than $50 \%$ growth proliferation were further diluted serially (in a concentration ranges of 0.33 to $40 \mu \mathrm{g} / \mathrm{mL}$ ) and tested for $\mathrm{IC}_{50}$ determinations. Afterwards, samples with $\mathrm{IC}_{50}$ value below and around $30 \mu \mathrm{g} / \mathrm{mL}$ on the above leukemia cells were further tested on the solid cancer cells in a concentration ranges of 0.33 to $40 \mu \mathrm{g} / \mathrm{mL}$. The viability was evaluated based on a comparison with untreated cells. $\mathrm{IC}_{50}$ values represent the compound's concentrations required to inhibit $50 \%$ of cell proliferation and were calculated from a calibration curve by linear regression using Microsoft Excel.

\section{Determination of cell cycle distribution and apoptosis by flow cytometry}

The cell cycle analysis was performed by flow cytometry using the Vybrant $^{\oplus}$ DyeCycle $^{\mathrm{Tm}}$ Violet (Invitrogen). This dye is a DNA-selective, cell membrane-permeant, and non-fluorescent stain that uses the violet laser for DNA content analysis in living cells. Vybrant ${ }^{\circ}$ DyeCycle $^{\mathrm{Tm}}$ Violet is fluorescent upon binding to double-stranded DNA. Leukemia CCRF-CEM cells $\left(1 \times 10^{6}\right)$ were treated with concentrations equivalent to the $\mathrm{IC}_{50}$ values of the four most active plant extracts namely those from Ononis serrata (SY160), Haplophyllum tuberculatum (SY177), Pulicaria crispa (SY179), and Achillea beiberstenii (SY200), for $24 \mathrm{~h}$. Following incubation, $1 \mu \mathrm{L}$ of Vybrant ${ }^{\odot}$ DyeCycle $^{\mathrm{Tm}}$ Violet was added to $1 \mathrm{~mL}$ of cell suspension and incubated for $30 \mathrm{~min}$ at $37^{\circ} \mathrm{C}$. Cells were measured on a LSR-Fortessa FACS analyzer (Becton-Dickinson, Germany). For each sample $10^{4}$ cells were counted. Vybrant $^{\oplus}$ DyeCycle $^{\mathrm{Ts}}$ Violet was measured at an excitation of $440 \mathrm{~nm}$. Cytographs were analyzed using FlowJo software (Celeza, Switzerland).

\section{Caspase-Glo 3/7, caspase-Glo 8 and caspase-Glo 9 assay}

The influence of extracts SY160, SY177, SY179, and Ach-b on caspase 3/7, caspase 8 and caspase 9 activities in CCRFCEM leukemia cells was detected using Caspase-Glo 3/7, Caspase-Glo 8 and Caspase-Glo 9 Assay kits (Promega,
Germany). Cells cultured in RPMI were seeded in 96-well plates and treated with the sample $\left(2 \times \mathrm{IC}_{50}\right.$ and $\left.\mathrm{IC}_{50}\right)$ or DMSO (solvent control). After $6 \mathrm{~h}$ treatment, $100 \mu \mathrm{L}$ of caspase reagent were added to each well, mixed and incubated for $1 \mathrm{~h}$ at room temperature. Luminescence was measured using well Infinite M2000 Pro $^{\mathrm{TM}}$ instrument (Tecan). Caspase activity was expressed as percentage of the untreated control.

\section{Analysis of mitochondrial membrane potential (MMP)}

The effects of extracts SY160, SY177, SY179, and Ach-b on the MMP were analyzed by $5,5^{\prime}, 6,6^{\prime}$-tetrachloro-1,1',3,3' tetraethylbenzimidazolylcarbocyanine iodide) (JC-1; Biomol, Germany) staining. JC-1 is a dye that can selectively enter into mitochondria and exhibits an intense red and green fluorescence in healthy mitochondria with normal membrane potentials. In cells with reduced MMP, the red fluorescence disappears and the unhealthy cells show only green fluorescence. Briefly, $1 \times 10^{6}$ CCRF-CEM cells treated with different concentrations of compound or DMSO (solvent control) for $24 \mathrm{~h}$ were incubated with JC-1 staining solution according to the manufacturer's protocol for $30 \mathrm{~min}$. Subsequently, cells were measured in a LSR-Fortessa FACS analyzer (Becton-Dickinson). For each sample, $1 \times 10^{4}$ cells were counted. The red JC-1 signal was measured with $561 \mathrm{~nm}$ excitation $(150 \mathrm{~mW})$ and detected using a 586/ $15 \mathrm{~nm}$ bandpass filter. The green JC-1 signal was analyzed with $488 \mathrm{~nm}$ excitation $(25 \mathrm{~mW})$ and detected using a $530 /$ $30 \mathrm{~nm}$ bandpass filter. All parameters were plotted on a logarithmic scale. Cytographs were analyzed using FlowJo software (Celeza, Switzerland).

\section{Antibacterial assay}

\section{Bacterial strains and culture media}

The studied microorganisms included the reference (from the American Type Culture Collection) and multidrug-resistant (MDR) clinical strains of Escherichia coli (ATCC8739 and AG100ATET), Enterobacter aerogenes (ATCC13048 and CM64), Klebsiella pneumoniae (ATCC11296 and KP63) and Pseudomonas aeruginosa (PA01 and PA124). They were maintained in Nutrient Broth supplemented at $4^{\circ} \mathrm{C}$ and activated on a fresh appropriate Mueller Hinton Agar plates $24 \mathrm{~h}$ prior to any antimicrobial test. The Mueller Hinton Broth (MHB) was also used for the all antibacterial assays.

\section{Bacterial susceptibility determinations}

The MICs were determined using the rapid INT colorimetric assay [34,35]. Briefly, the test samples were first dissolved in DMSO/MHB. The solution obtained was then added to MHB, and serially diluted two fold (in a 96- wells microplate). One hundred microlitres $(100 \mu \mathrm{L})$ of inoculum $\left(1.5 \times 10^{6} \mathrm{CFU} / \mathrm{mL}\right)$ prepared in $\mathrm{MHB}$ was then added. The plates were covered with a sterile plate 
sealer, then agitated to mix the contents of the wells using a shaker and incubated at $37^{\circ} \mathrm{C}$ for $18 \mathrm{~h}$. The final concentration of DMSO was $2.5 \%$ and does not affect the microbial growth. Wells containing MHB, $100 \mu \mathrm{L}$ of inoculum and DMSO at a final concentration of $2.5 \%$ served as negative control (this internal control was systematically added). Chloramphenicol was used as reference antibiotic. The MICs of samples were detected after $18 \mathrm{~h}$ incubation at $37^{\circ} \mathrm{C}$, following addition of $40 \mu \mathrm{L}$ of a $0.2 \mathrm{mg} / \mathrm{mL}$ INT solution and incubation at $37^{\circ} \mathrm{C}$ for 30 minutes. Viable bacteria reduce the yellow dye to pink. MIC was defined as the lowest sample concentration that exhibited complete inhibition of microbial growth and then prevented this change [36]. All assays were performed in triplicate and repeated thrice.

\section{Statistical analysis}

Statistical analysis of all data was performed using a Student's $t$-test or Kruskal-Wallis test followed by Dunn's post-hoc multiple comparison test (Graph-Pad Prism 5.01; GraphPad Software, Inc., CA, USA). A significance level of $P<0.05$ denoted significance in all cases.

\section{Results}

\section{Cytotoxicity}

In the present work, the cytotoxicity of twenty six Saudi Arabian plants (Table 1) was initially evaluated against leukemia CCRF-CEM and HL60 cell lines. The results depicted in Figure 1 show that only the extract from Heliotropium ramosissimum (SY183) did not prevent the growth of the two cell line. Besides, those from Teucrium oliverianum (SY175), Echium arabicum (SY176) and Emex spinosa (SY194) did not prevented the growth of CCRF-CEM cells. All other extracts were able to inhibit in various extents the proliferation of CCRF-CEM as well as HL60 cells. More than $50 \%$ inhibition of the growth of CCRFCEM and HL60 were exhibited by the extracts from Achillea beiberstenii (SY-200; 76.27\% and $66.22 \%$ respectively) as well as Ononis serrata (SY160; 64.32\% and $71.16 \%$ respectively). Also, more than $50 \%$ growth inhibition of CCRF-CEM was recorded with Haplophyllum tuberculatum (SY177; 63.21\%), Senna italica (SY178; 53.57\%), Pulicaria crispa (SY179; 76.17\%), Rhantarium epapposum (SY180; 66.71\%), Anthemis deserti (SY185; 65.54\%), Ziziphus nummularia (SY188; 74.99\%), Rhazya strict (SY195; 66.63\%) and Artemisia monosperma (SY198; 67.66\%). The $\mathrm{IC}_{50}$ values of the ten above samples were then determined on CCRF-CEM cells whilst those of Ach-b and SY160 were evaluated on HL60 cells (Table 2). Apart from SY178 $\left(\mathrm{IC}_{50}\right.$ value of $37.13 \mu \mathrm{g} /$ $\mathrm{mL})$ and SY180 ( $\mathrm{IC}_{50}$ value of $37.13 \mu \mathrm{g} / \mathrm{mL}$ ) against CCRF-CEM cells, other tested extracts displayed values below or around $30 \mu \mathrm{g} / \mathrm{mL}$. The best activities were recorded with SY177 $\left(\mathrm{IC}_{50}\right.$ of $\left.9.94 \mu \mathrm{g} / \mathrm{mL}\right)$ and SY179 $\left(\mathrm{IC}_{50}\right.$ of $1.81 \mu \mathrm{g} / \mathrm{mL})$ against CCRF-CEM as well as Ach-b $\left(\mathrm{IC}_{50}\right.$ of $9.30 \mu \mathrm{g} / \mathrm{mL})$ and SY160 $\left(\mathrm{IC}_{50}\right.$ of $\left.5.06 \mu \mathrm{g} / \mathrm{mL}\right)$ against HL60 cells. Samples with $\mathrm{IC}_{50}$ value below and around $30 \mu \mathrm{g} / \mathrm{mL}$ (SY177, SY179, SY185, SY188, SY189, SY198, SY160 and Sch-b) were further tested on the solid cancer cells (Table 3) including both sensitive and resistant phenotypes. The results showed that only the extracts from SY177 and SY179 were toxic to the seven solid cancer cells with the highest $\mathrm{IC}_{50}$ values of $31.64 \mu \mathrm{g} / \mathrm{mL}$ (SY177 against Hep-G2 cells). Other samples showed selective activities, the extracts of SY160 and Ach-b being active on six of the seven solid cancer cells tested. Consequently, the extracts SY160, SY177, SY179, and Ach-b which showed the best activities were further investigated for

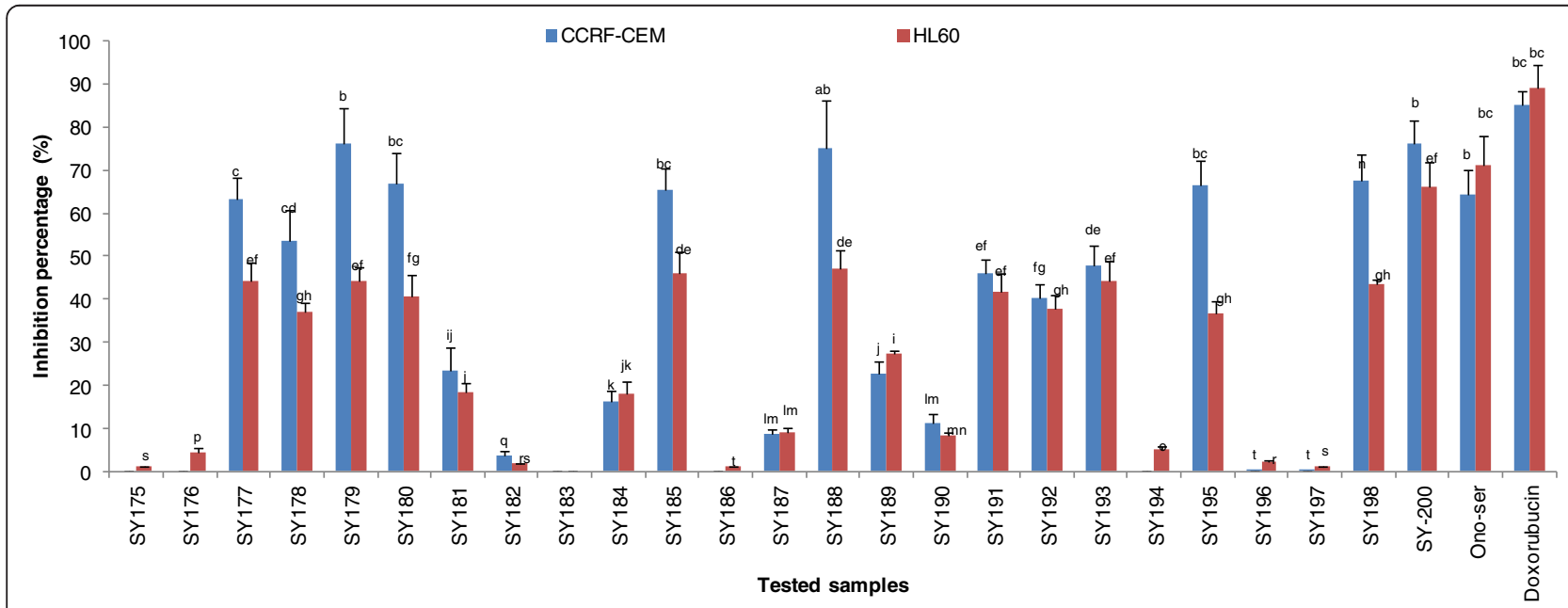

Figure 1 Inhibitory percentage (\%) of plant extracts at $40 \mu \mathrm{g} / \mathrm{mL}$ and doxorubicin (10 $\mu \mathrm{g} / \mathrm{mL})$ on leukemia CCRF-CEM and HL60 cancer cell lines. Data with different superscript letters are significantly different $(P<0.05)$. 
Table $2 \mathrm{IC}_{50}$ values of Saudi Arabian plants towards leukemia cancer cell lines CCRF-CEM and HL60 as determined by the resazurin assay

\begin{tabular}{llll}
\hline Tested samples & $\begin{array}{l}\text { Samples } \\
\text { code }\end{array}$ & \multicolumn{2}{l}{ Cell lines and IC $\mathbf{5 0}(\boldsymbol{\mu g} / \mathbf{m L})$} \\
\cline { 3 - 4 } & CCRF-CEM & HL60 \\
\hline Haplophyllum tuberculatum & SY177 & 9.94 & - \\
Senna italica & SY178 & 37.13 & - \\
Pulicaria crispa & SY179 & 1.81 & - \\
Rhantarium epapposum & SY180 & 31.9 & - \\
Anthemis deserti & SY185 & 30.08 & - \\
Ziziphus nummularia & SY188 & 16.6 & - \\
Rhazya strict & SY195 & 22.35 & - \\
Artemisia monosperma & SY198 & 19.64 & - \\
Ononis serrata & SY160 & 17.44 & 9.30 \\
Achillea beiberstenii & SY-200 & 18.11 & 5.06 \\
Doxorubicin & & 0.11 & 0.40 \\
\hline
\end{tabular}

$(-):>40 \mu \mathrm{g} / \mathrm{mL}$.

their effects on the cell cycle distribution, apoptosis, caspase 3/7, 8 and 9 activities as well as on MMP using CCRF-CEM cells as model for the studies.

\section{Cell cycle distribution and apoptosis}

The effects of extracts SY160, SY177, SY179, and Ach-b on the cell cycle distribution of CCRF-CEM cells are summarized in Figure 2. All the four extracts as well as doxorubicin considerably altered the distribution of the different cell cycle phases after $24 \mathrm{~h}$. All the four extracts also significantly induced apoptosis after $24 \mathrm{~h}$ treatment with percentages of sub-G0/G1 phase of 14.6\% for SY177, 66.9\% for SY179, 40.2\% for Ach-b and 65.7\% for SY160.

Effect on the mitochondrial membrane potential (MMP) Since the breakdown of the MMP is amongst the sequences of events occurring during the apoptotic pathway, we assessed the involvement of extracts SY160, SY177, SY179, and Ach-b as well as that of the reference drug vinblastine in the process. The results summarized in Figure 3 show that the four extracts as well as vinblastine were able to alter the MMP in CCRF-CEM upon $24 \mathrm{~h}$ treatment. When cells were treated with concentrations equivalent to the $\mathrm{IC}_{50}$ values of the samples, percentages of alterations of the MMP observed were found to be $16.7 \%, 27.7 \%, 27.8 \%$ and $28.0 \%$ respectively for Ach-b, SY160, SY177, and SY179. However, such alteration was still lower than that of vinblastine (48.6\%).

\section{Effect on the activity of caspases 3/7, 8 and 9}

The influence of extracts SY160, SY177, SY179, and Ach-b on caspases 3/7, 8 and 9 activities in CCRF-CEM cells were investigated. None of the four samples induced the activation of each of the studied enzymes (data not shown).

\section{Antimicrobial activity}

The twenty six plant extracts tested for their cytotoxicity were also, screened for their antibacterial activities against eight bacterial strains belonging to four species, Escherichia coli, Enterobacter aerogenes, Klebsiella pneumoniae and Pseudomonas aeruginosa. Only Ach-b displayed moderate antibacterial activities against $E$. coli and $E$. aerogenes ATCC strains (MIC of $256 \mu \mathrm{g} / \mathrm{mL}$ ), $\mathrm{AG} 100 \mathrm{~A}_{\mathrm{TeT}}$ and $K$. pneumoniae ATCC strains (MIC of $128 \mu \mathrm{g} / \mathrm{mL}$ ). This extracts as well as the twenty-five others were not active on bacterial species.

\section{Discussion}

According to the criteria of the American National Cancer Institute, as reported by Suffness and Pezzuto [37], $30 \mu \mathrm{g} / \mathrm{mL}$ is the upper $\mathrm{IC}_{50}$ limit considered promising for purification of a crude extract. Therefore, the highest

Table 3 Cytotoxicity of Saudi Arabian plants towards sensitive and drug-resistant solid cancer cell lines and normal cells as determined by the resazurin assay

\begin{tabular}{|c|c|c|c|c|c|c|c|c|c|}
\hline \multirow[t]{2}{*}{ Tested samples } & \multirow{2}{*}{$\begin{array}{l}\text { Sample } \\
\text { code }\end{array}$} & \multicolumn{8}{|c|}{ Cell lines, $\mathrm{IC}_{50}(\mu \mathrm{g} / \mathrm{mL})$ and degree of resistance* } \\
\hline & & $\begin{array}{l}\text { MDA-MB-231/ } \\
\text { pcDNA }\end{array}$ & $\begin{array}{l}\text { MDA-MB-231/ } \\
\text { BCRP }\end{array}$ & $\begin{array}{l}\text { HCT116 } \\
p 53^{+/+}\end{array}$ & $\begin{array}{l}\text { HCT116 } \\
p 53^{-/-}\end{array}$ & U87MG & $\begin{array}{l}\text { U87MG } \\
\Delta E G F R\end{array}$ & HepG2 & AML 12 \\
\hline Haplophyllum tuberculatum & SY177 & 11.92 & $26.65(2.24)$ & 2.42 & $3.30(1.36)$ & 15.03 & $27.67(1.84)$ & 31.64 & - \\
\hline Pulicaria crispa & SY179 & 14.6 & $8.37(0.57)$ & 2.79 & $2.58(0.92)$ & 4.31 & $27.46(6.37)$ & 27.85 & - \\
\hline Anthemis deserti & SY185 & - & - & 24.48 & $31.94(1.30)$ & - & - & - & - \\
\hline Ziziphus nummularia & SY188 & - & - & - & - & - & - & - & - \\
\hline Neurada procumbens & SY189 & - & - & - & - & 3.01 & - & - & - \\
\hline Artemisia monosperma & SY198 & - & $26.16(<0.65)$ & 7.35 & $6.65(0.90)$ & 25.25 & $24.95(0.99)$ & - & - \\
\hline Ononis serrata & SY160 & 19.28 & $25.09(1.30)$ & 14.9 & $21.94(1.47)$ & 28.58 & 31.09 (1.09) & - & - \\
\hline Achillea beiberstenii & SY-200 & 10.48 & $22.32(2.13)$ & 17.09 & $17.31(1.01)$ & - & $19.24(<0.48)$ & 27.28 & - \\
\hline Doxorubicin & & 1.10 & $7.83(7.12)$ & 1.41 & $4.06(2.88)$ & 1.06 & $6.11(5.76)$ & 1.41 & - \\
\hline
\end{tabular}

$\left(^{*}\right)$ : The degree of resistance was determined as the ratio of $I C_{50}$ value of the resistant $/ \mathrm{IC}_{50}$ sensitive cell line; $(-):>40 \mu \mathrm{g} / \mathrm{mL}$. 

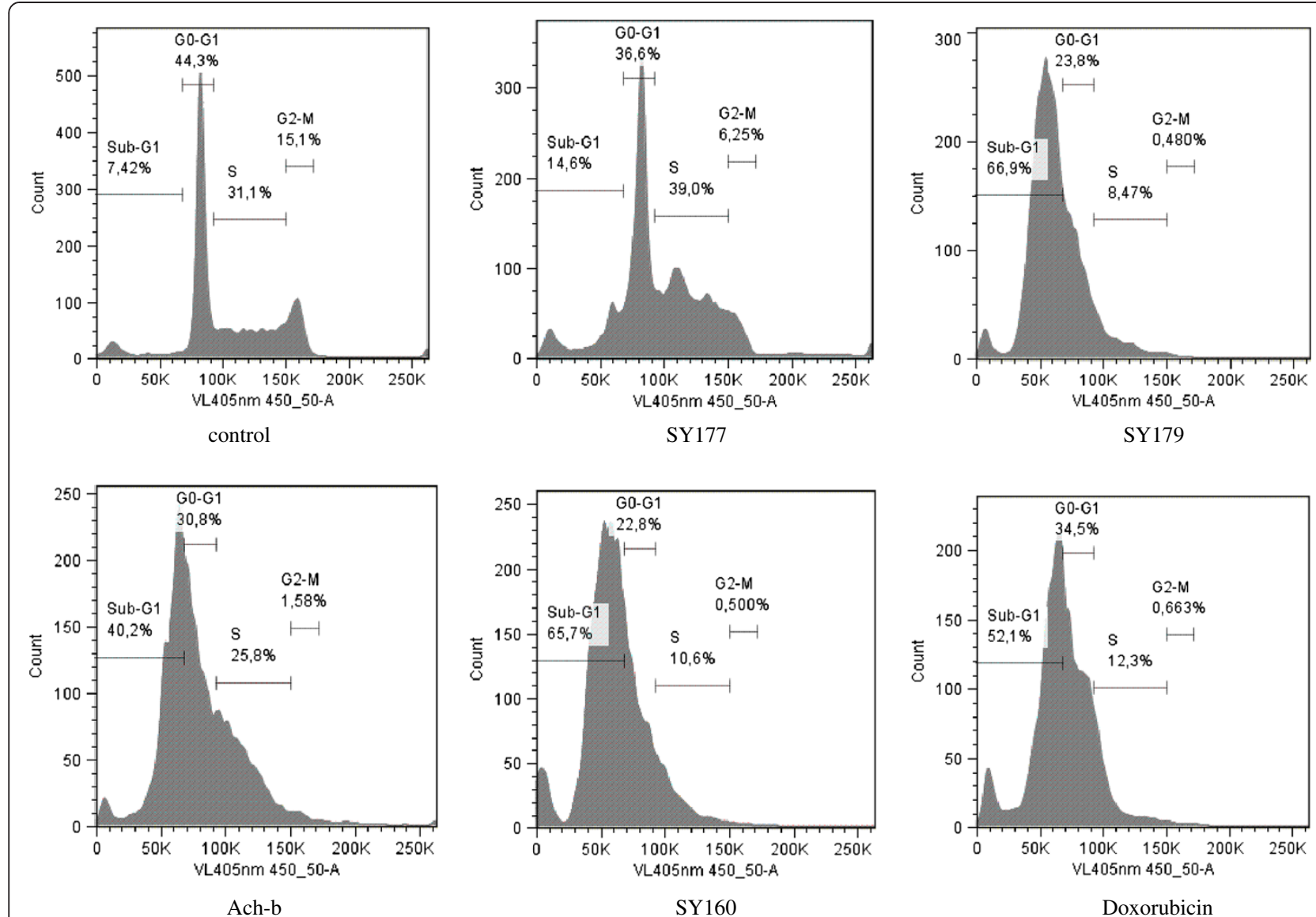

Figure 2 Cell cycle distribution of leukemia CCRF-CEM cells treated with selected plant extracts and doxorubicin at their IC 50 values for $24 \mathrm{~h}$.

concentration tested $(40 \mu \mathrm{g} / \mathrm{mL})$ in our screening was slightly above this limit. Herein, $\mathrm{IC}_{50}$ values below $30 \mu \mathrm{g} /$ $\mathrm{mL}$ were recorded with the crude extract from SY160 and Ach-b against the two leukemia cell lines, CCRF-CEM and HL60 (Table 2). In addition, the two plant extracts also displayed cytotoxic activities with $\mathrm{IC}_{50}$ values below $30 \mu \mathrm{g} / \mathrm{mL}$ against six of the seven solid cancer cells (Table 3). This highlights the role of these two plants as potential source of products to combat both hematological and solid cancers. Also the extracts from SY177 and SY179 showed good activities against the leukemia CCRF-CEM cells $\left(\mathrm{IC}_{50}\right.$ value of 9.94 and $1.81 \mu \mathrm{g} / \mathrm{mL}$ respectively) and all the seven studied solid cancer cells, with the $\mathrm{IC}_{50}$ values below $10 \mu \mathrm{g} / \mathrm{mL}$ against MDA-MB231-BCRP $(8.37 \mu \mathrm{g} / \mathrm{mL}$ for SY179), HCT116 WT $(2.42 \mu \mathrm{g} / \mathrm{mL}$ for SY177 and $2.79 \mu \mathrm{g} /$ $\mathrm{mL}$ for SY179). HCT116 (p53-/-) (3.30 $\mu \mathrm{g} / \mathrm{mL}$ for SY177 and $2.58 \mu \mathrm{g} / \mathrm{mL}$ for SY179) and against U78MG $(2.58 \mu \mathrm{g} /$ $\mathrm{mL}$ for SY179). These data also suggest that the two plant extracts can be potential source of cytotoxic agents. This is remarkable, since the extracts also exhibited considerable activity towards genetically modified cell lines, which harbor cDNAs encoding for proteins mediating resistance to standard anticancer drugs, such as the breast cancer resistance protein (BCRP) and an mutation-activated epidermal growth factor receptor (EGFR) or which were knocked-out in the expression of the tumor suppressor p53. Importantly, the degrees of resistance of the four most active plant extracts Ononis serrata (SY160), Haplophyllum tuberculatum (SY177), Pulicaria crispa (SY179), and Achillea beiberstenii (SY-200) were generally lower than that of doxorubicin for the corresponding drugresistant cell lines (Table 3). Besides, collateral sensitivity (resistant cells being more sensitive than their sensitive parental cell lines with degrees of resistance below 1) was observed with each of the four plant extracts on at least one MDR cell lines (Table 3). This suggests that the extracts from Haplophyllum tuberculatum, Pulicaria crispa, Ononis serrata and Achillea beiberstenii might be useful to fight MDR cancer cells. Interestingly, normal AML12 hepatocytes were more resistant to the extracts than HepG2 hepatocellular carcinoma cells. This may be taken as a hint that these compounds exhibit some tumor specificity, although their toxicity towards normal organs needs to be further explored. Consequently, the four best plant extracts, namely those from Ononis serrata (SY160), Haplophyllum tuberculatum (SY177), Pulicaria 


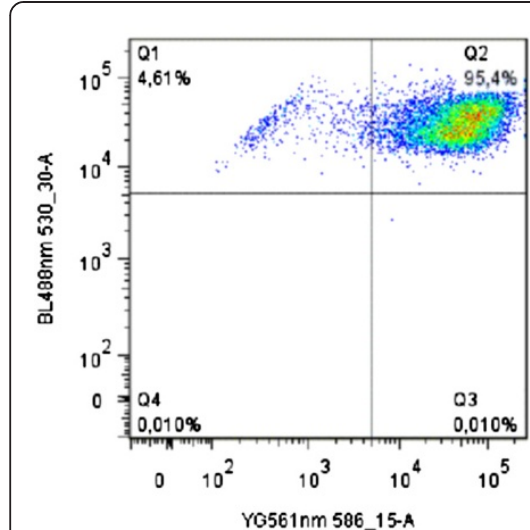

A

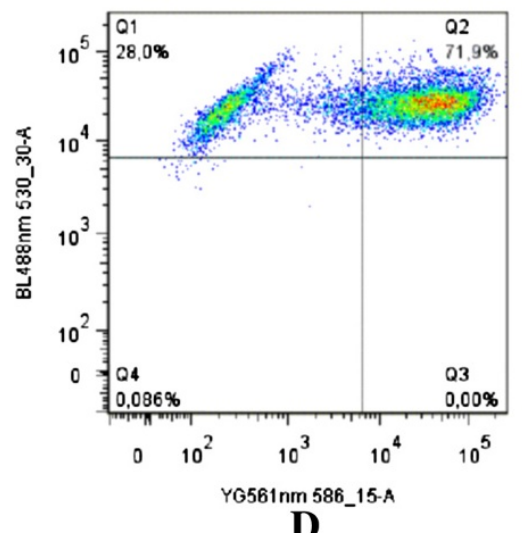

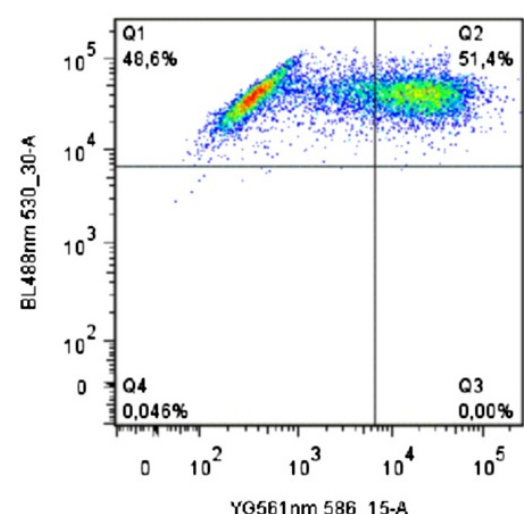

B

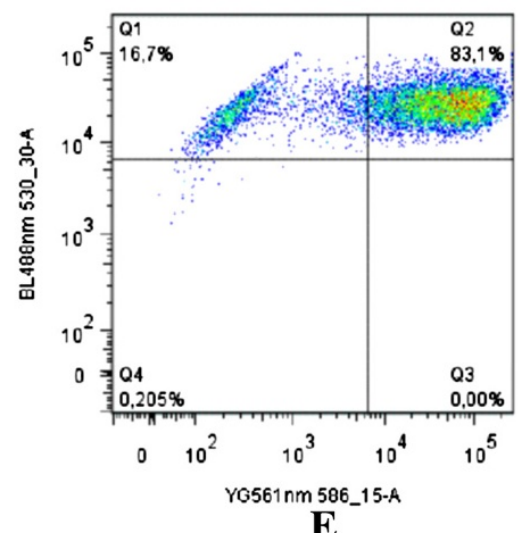

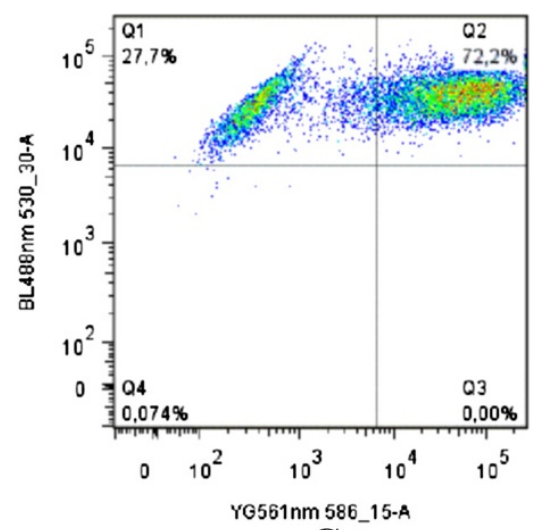

C

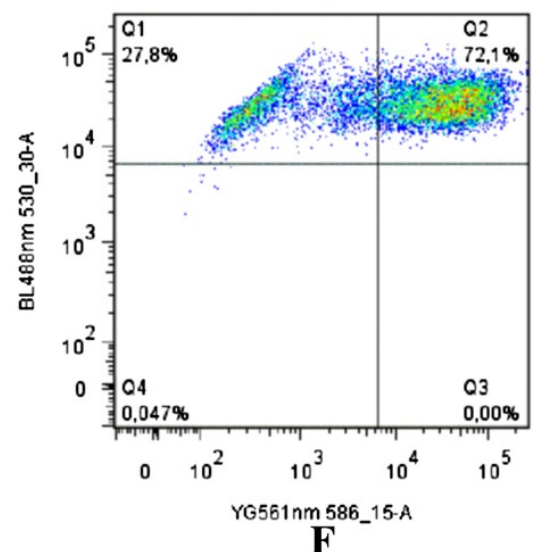

Figure 3 Effect of selected plant extracts and vinblastine on the MMP of CCRF-CEM cells after $24 \mathrm{~h}$ treatment at their IC ${ }_{50}$ values; The IC $_{\mathbf{5 0}}$ values: $\mathbf{0 . 2 0} \boldsymbol{\mu M}$ for VIN (this study). Samples: control (A), vinblastine (B), SY177 (C), SY179 (D), Ach-b (E), SY160 (F). Q1 represent cells with healthy MMP whilst Q2-Q4 are those with altered MMP.

crispa (SY179), and Achillea beiberstenii (SY-200) were selected for further mechanistic studies. It was observed that SY160, SY177, SY179, and Ach-b induce apoptosis in leukemia CCRF-CEM cells (Figure 2). The percentages of sub-G0/G1 phase upon treatment with SY160 (65.7\%) and SY179 (66.9\%) were higher than those of doxorubicin (52.1\%) (Figure 2) highlighting their strong apoptotic inducing effects. SY177 and Ach-b induce cell cycle arrest in G0/G1 and S phases whilst SY160 and SY179 induce arrest in G0/G1 phase (Figure 2). Caspases, or cysteineaspartic proteases are a family of cysteine proteases that play essential roles in apoptosis, necrosis, and inflammation [38]. As the extracts SY160, SY177, SY179, and Achb were found to strongly induce apoptosis in CCRF-CEM cells (Figure 2), we evaluated the involvement of initiator caspases 8 and 9 as well as that of effector caspases 3 and 7 in this process. Unfortunately, none of the four studied extracts (SY160, SY177, SY179, and Ach-b) activated these enzymes (data not shown), suggesting that it is not the main pathways involved in apoptosis in CCRF-CEM cells. Hopefully, when assaying their effects on MMP, the four plant extracts were found to induce the dysfunction of the mitochondrial membrane in CCRFCEM cells (Figure 3). The alteration of the MMP can therefore be suggested as one of the possible mechanisms of apoptosis induced by SY160, SY 177, SY179, and Ach-b.

Phytochemicals are routinely classified as antimicrobials on the basis of susceptibility tests that produce $\mathrm{MIC}$ in the range of 100 to $1000 \mathrm{mg} / \mathrm{mL}$ [39]. Activity is considered to be significant if MIC values are below $100 \mu \mathrm{g} / \mathrm{mL}$ for crude extracts and moderate when $100<$ $\mathrm{MIC}<625 \mu \mathrm{g} / \mathrm{mL}$ [40]. In this study, only Ach-b displayed moderate antibacterial activities against E. coli and E. aerogenes and K. pneumoniae. Therefore, none of the studied samples could be considered as promising source of antimicrobial compounds.

\section{Conclusions}

Finally, the results of the present investigation highlight the cytotoxic potential of the studied Saudi Arabian medicinal plant extracts, especially those from Haplophyllum tuberculatum, Pulicaria crispa, Ononis serrata and Achillea beiberstenii. The isolation of active constituents from these plants will further be performed. 


\section{Competing interests}

The authors declare that they have no competing interest.

\section{Authors' contributions}

VK, BW, STL, MSA and AGF carried out the study; VK, AAS and TE designed the experiments. VK and AAS wrote the manuscript; VK and TE supervised the work; all authors read and approved the final manuscript.

\section{Acknowledgements}

The authors would like to extend their appreciation to the Deanship of Scientific Research at King Saud University for its funding of this work through research group no RGP- VPP-262. Dr. Victor Kuete is very grateful to the Alexander von Humboldt foundation for an 18 months' fellowship in Germany through the "Georg Foster Research Fellowship for Experienced Researcher" program for funding this work. Authors are also thankful to the Institute of Molecular Biology GmbH (IMB) (Mainz, Germany) where the flow cytometry experiments were performed.

\section{Author details}

'Department of Pharmaceutical Biology, Institute of Pharmacy and Biochemistry, University of Mainz, Staudinger Weg 5, 55128 Mainz, Germany. ${ }^{2}$ Department of Biochemistry, Faculty of Science, University of Dschang, P.O. Box 67, Dschang, Cameroon. ${ }^{3}$ Pharmcognosy Department, College of Pharmacy, King Saud University, P.O. Box 2457, Riyadh 11451, Saudi Arabia. ${ }^{4}$ Phytochemistry Department, National Research Centre, 12311 Dokki, Cairo, Egypt.

Received: 2 February 2013 Accepted: 9 December 2013 Published: 12 December 2013

\section{References}

1. Rahman MA, Mossa JS, Al-Said MS, Al-Yahya MA: Medicinal plant diversity in the flora of Saudi Arabia 1: a report on seven plant families. Fitoterapia 2004, 75:149-161.

2. Arzi A, Namjouyan F, Sarahroodi S, Khorasgani ZN, Macvandi E: The study of antinociceptive effect of hydroalcoholic extract of Teucrium oliverianum (a plant used in southern Iranian traditional medicine) in rat by formalin test. Pak J Biol Sci 2011, 14:1066-1069.

3. Ljubuncic P, Dakwar S, Portnaya I, Cogan U, Azaizeh H, Bomzon A: Aqueous extracts of Teucrium polium possess remarkable antioxidant activity in vitro. Evid Based Complement Alternat Med 2006, 3:329-338.

4. Vukovic N, Milosevic T, Sukdolak S, Solujic S: Antimicrobial activities of essential oil and methanol extract of Teucrium montanum. Evid Based Complement Alternat Med 2007, 4:17-20.

5. Abdel-Sattar E, Harraz FM, Al-Ansari SMA, El-Mekkawy S, Ichino C, Kiyohara $\mathrm{H}$, Otoguro K, Omura S, Yamada H: Antiplasmodial and antitrypanosomal activity of plants from the Kingdom of Saudi Arabia. J Nat Med 2009, 63:232-239.

6. Mossa JS, Al-Yahya MA, Al-Meshal IA: Medical plants of Saudi Arabia. 1st edition. Riyadh: King Saud University Libraries; 1987.

7. Al-Yahya MA, Al-Rehaily AJ, Mohammed SA, Mansour S, Farouk S: New alkaloid from Haplophyllum tuberculatum. J Nat Prod 1992, 55:899-903.

8. Bruschi P, Morganti M, Mancini M, Signorini MA: Traditional healers and laypeople: a qualitative and quantitative approach to local knowledge on medicinal plants in Muda (Mozambique). J Ethnopharmacol 2011, 138:543-563.

9. Ross SA, El-Sayed KA, El-Sohly MA, Hamann MT, Abdel-Halim OB, Ahmed AF, Ahmed MM: Phytochemical analysis of Geigeria alata and Francoeuria crispa essential oils. Planta Med 1997, 63:479-482.

10. Shama IY, Shama IYA, Adam SEl: Comparative toxicity of Trichodesma africanum and Rhanterium epapposum aerial parts aqueous and methanolic extracts on Wistar rats. J Pharmacol Toxicol 2012, 7:128-138.

11. Li AR: Flora of China. Beijing, China: Science Publishing House; 1998:147-166.

12. Zhang GQ, Zhao HP, Wang ZY, Cheng JR, Tang XM: Recent advances in the study of chemical constituents and bioactivity of Rumex L. World Sci Tech (Mod Trad Chin Med) 2008, 10:86-93.

13. Editorial Commission of China: Flora of Chinese Academy of Sciences. Beijing, China: Science Press; 1998:151.

14. Hajhashemi V, Rabbani M, Ghanadi A, Davar E: Evaluation of antianxiety and sedative effects of essential oil of Ducrosia anethifolia in mice. Clinics 2010, 65:1037-1042.
15. Medina JCM, Gauze GF, Vidotti GJ, Sarragiotto MH, Basso EA, Peixoto JLB: Structural characterization of saturated pyrrolizidine alkaloids from Hilotrobium transalpinum var. transalpinum Vell by NMR spectroscopy and theoretical calculations. Tetrahedron Lett 2009, 50:2640-2642.

16. Serbian Academy of Sciences and Arts: Medicinal plants of Serbia. Scientific Book: Belgrade; 1985:131

17. Saroglou V, Dorizas N, Kypriotakis Z, Skaltsa HD: Analysis of the essential oil composition of eight Anthemis species from Greece. J Chromatogr A 2006, 1104:313-322.

18. El-Askary HI: Terpenoids from Cleome droserifolia (Forssk). Del Mol 2005, 10:971-977.

19. El-Toumy SA, El-Sharabasy FS, Ghanem HZ, El-Kady MU, Kassem AF: Phytochemical and pharmacological studies on Zilla spinosa. Austr J Basic Appl Sci 2011, 5:1362-1370.

20. Bachaya HA, lqbal Z, Khan MN, Sindhu ZU, Jabbar A: Anthelmintic activity of Ziziphus nummularia (bark) and Acacia nilotica (fruit) against

Trichostrongylid nematodes of sheep. J Ethnopharmacol 2009, 123:325-329.

21. Elmann A, Mordechay S, Erlank H, Telerman A, Rindner M, Ofir R: Antineuroinflammatory effects of the extract of Achillea fragrantissima. BMC Complement Altern Med 2011, 11:98.

22. Sharma GL, Singh RP, Chauhan AKS, Mishraj K: Some economic and medicinal plants used by Tribals in Ashoknagar and Gunadisricts of M.P. Indian J L Sci 1 2012, 2:115-117.

23. Khalil M, Mohamed G, Dallak M, Al-Hashem F, Sakr H, Eid RA, Adly MA, Al-Khateeb M, Banihani S, Hassan Z, Bashir N: The effect of Citrullus colocynthis pulp extract on the liver of diabetic rats a light and scanning electron microscopic study. Am J Biochem Biotechnol 2010, 6:155-163.

24. El-Mawla AMAA, Ibraheim ZZ: Methyl jasmonate induced accumulation of biologically active phenolic compounds in cell cultures of Emex spinosa (L.) Campd. Spatula DD, 1:67-71.

25. Al Ghunaymi A: Encyclopaedia of the United Arab Emirates plants used in folk medicine. United Arab Emirates University Press: Al-Ain, (in Arabic) 1992:345-346.

26. World Health Organisation (WHO) and Institute of Materia Medica (IMM): Medicinal plants in Vietnam. Hanoi: Scientific and Technical Publishing House; 1990:342-343.

27. Nguyen AT, Fontaine J, Malonne H, Vanhaelen M, Dubois J, Ky Pham T, Duez P: Cytotoxicity of five plants used as anticancer remedies in Vietnam traditional medicine. Recent Progress Medicinal Plants, Studium Press, Texas, USA 2005, 15:145-155.

28. Sathiyamoorthy $P$, Lugasi-Evgi $H$, Schlesinger $P$, Kedar I: Screening for cytotoxic and antimalarial activities in desert plants of the Negev and Bedouin market plant products. Pharm Biol 1999, 37:188-195.

29. Hijazi AM, Salhab AS: Effects of Artemisia monosperma ethanolic leaves extract on implantation, mid-term abortion and parturition of pregnant rats. J Ethnopharmacol 2010, 128:446-451.

30. Liebezeit G: Ethnobotany and phytochemistry of plants dominant in salt marshes of the Lower Saxonian Wadden Sea, southern North Sea. Senckenbergiana maritima 2008, 38:1-30.

31. Benedek B, Kopp B, Melzig MF: Achillea millefolium L.S. I. Is the antiinflammatory activity mediated by protease inhibition? J Ethnopharmacol 2007, 113:312-317.

32. Efferth T, Sauerbrey A, Olbrich A, Gebhart E, Rauch P, Weber HO, Hengstler JG, Halatsch ME, Volm M, Tew KD, Ross DD, Funk JO: Molecular modes of action of artesunate in tumor cell lines. Mol Pharmacol 2003, 64:382-394.

33. O'Brien J, Wilson I, Orton T, Pognan F: Investigation of the Alamar Blue (resazurin) fluorescent dye for the assessment of mammalian cell cytotoxicity. Eur J Biochem 2000, 267:5421-5426.

34. Eloff JN: A sensitive and quick microplate method to determine the minimal inhibitory concentration of plant extracts for bacteria. Planta Med 1998, 64:711-713.

35. Mativandlela SPN, Lall N, Meyer JJM: Antibacterial, antifungal and antitubercular activity of (the roots of) Pelargonium reniforme (CURT) and Pelargonium sidoides (DC) (Geraniaceae) root. S Afr J Bot 2006, 72:232-237.

36. Kuete V, Ngameni B, Fotso Simo CC, Kengap TR, Tchaleu NB, Meyer JJM, Lall N, Kuiate JR: Antimicrobial activity of the crude extracts and compounds from Ficus chlamydocarpa and Ficus cordata (Moraceae). J Ethnopharmacol 2008, 120:17-24.

37. Suffness M, Pezzuto JM: Assays related to cancer drug discovery. In Methods in Plant Biochemistry: Assays for Bioactivity. Edited by Hostettmann K. London: 6. Academic Press; 1990:71-133. 
38. Alnemri ES, Livingston DJ, Nicholson DW, Salvesen G, Thornberry NA, Wong WW, Yuan J: Human ICE/CED-3 protease nomenclature. Cell 1996, 87:171.

39. Simões M, Bennett RN, Rosa EA: Understanding antimicrobial activities of phytochemicals against multidrug resistant bacteria and biofilms. Nat Prod Rep 2009, 26:746-757.

40. Kuete V: Potential of Cameroonian plants and derived-products against microbial infections: a review. Planta Med 2010, 76:1479-1491.

doi:10.1186/1472-6882-13-354

Cite this article as: Kuete et al: Cytotoxicity, mode of action and

antibacterial activities of selected Saudi Arabian medicinal plants. BMC

Complementary and Alternative Medicine 2013 13:354.

\section{Submit your next manuscript to BioMed Central and take full advantage of:}

- Convenient online submission

- Thorough peer review

- No space constraints or color figure charges

- Immediate publication on acceptance

- Inclusion in PubMed, CAS, Scopus and Google Scholar

- Research which is freely available for redistribution 